\title{
BRAZILIAN'S STRUCTURAL CHANGE AND ECONOMIC PERFORMANCE: STRUCTURALIST COMMENTS ON MACROECONOMICS POLICIES
}

\author{
Henrique Morrone*
}

\begin{abstract}
Resumo
Este estudo avalia o impacto das políticas macroeconômicas sobre o lado real da economia brasileira. Apresentamos um modelo estruturalista de crescimento com base em Rada (2007) para investigar o recente desempenho econômico do Brasil. A matriz de contabilidade social para o Brasil em 2006 serve de base para o modelo. Nós investigamos os efeitos de curto / médio prazo de quatro exercícios de simulação: um aumento no investimento autônomo (espíritos animais), um aumento nos salários formais, uma depreciação da taxa de câmbio, e um aumento do crescimento da produtividade do trabalho. Os resultados sugerem que a economia brasileira segue um regime de crescimento fracamente puxado pelos lucros. Nesse sentido, apenas políticas macroeconômicas que aumentam o investimento autônomo e a produtividade do trabalho podem estimular a economia.
\end{abstract}

Palavras-chave: Modelos estruturalistas; economias com excedente de trabalho; regimes alavancados por lucros/salários.

\begin{abstract}
This article evaluates the impact of macroeconomic policies on the real side of the Brazilian economy. We present a Structuralist model in growth terms based on Rada (2007) to investigate the recent economic performance of Brazil. The Social Accounting Matrix for Brazil in 2006 serves as a benchmark for our model. We investigate the short/medium term effects of four simulation exercises: a rise in autonomous investment (animal spirits), an increase in wages, a exchange rate depreciation, and a rise in labour productivity growth. The results suggest that the Brazilian economy is weakly profit-led. In this vein, only macroeconomic policies that increase autonomous investment and labour productivity can stimulate the economy.
\end{abstract}

Keywords: Structuralist models; Labour surplus economies; Wage/Profitled regimes

JEL classification: $\mathrm{O} 1, \mathrm{C} 1, \mathrm{D} 57$

DOI: http://dx.doi.org/10.1590/1413-8050/ea 155984

\footnotetext{
* Professor Adjunto da Universidade Federal do Rio Grande do Sul - UFRGS)
} 


\section{Introduction}

Structural transformation and economic growth are strongly related to economic development. Although economic growth and high productivity may be insufficient to create jobs and reduce poverty. To avoid jobless growth, labour transfer from low to high productivity sectors must take place. Creating better paid jobs in high productivity sectors is becoming pivotal to reach higher levels of economic development. A strong demand for sectors containing high productivity also remains essential. In this manner, underdevelopment is associated with a lack of dynamic structural transformation in the economy.

Because of the role of the informal sector as a reservoir of labour, it is important to evaluate the impact of macroeconomic policies on both the informal and formal sectors to assess the complexities of the process of economic expansion in Brazil. In this context, macroeconomic policies should improve the interrelationships between sectors, generating well paid jobs and economic growth.

This paper aims to present a Structuralist model to explore the effect of macroeconomic policies in Brazil after 2006. The Structuralist model presented here describes an open, developing economy with two sectors, two commodities, and three classes. We borrowed the model from Rada $(2007,2012)$. The two-sector Social Accounting Matrix (SAM) for Brazil in 2006 from Morrone (2015b) serves as our benchmark. This period was chosen as a benchmark for our simulations since it is the most recent SAM available in the literature that distinguishes between formal and informal activities ${ }^{1}$. We applied this model in the short/medium term to compare the effects of four experiments: a rise in autonomous investment (animal spirits), an increase in wages, an exchange rate depreciation, and a surge in labour productivity growth. We attempt to shed light on the possible effects of these simulation exercises on key macroeconomic variables.

The rest of the paper is organized as follows. We assess the sectoral contribution to output growth in Section 2. In Section 3, the schematic Social Accounting Matrix (SAM), the structuralist model and the data are presented. Four experiments are analysed in Section 4: a rise in autonomous investment, an increase in formal wages, an exchange rate depreciation, and a surge in the productivity growth rate. The remainder two sections exhibit results and conclusions.

\section{Sectoral Contribution to Economic Growth and Structural change during the 2000s in Brazil}

Economic development has a profound relationship with structural transformation in relation to activities that contain static and dynamic scale economies. Manufacturing and high tech services' performance are crucial to promote sustainable growth. These sectors can boost labour productivity through spillover effects and learning by doing. (The latter is present as a term of the economic regularity known as the Kaldor-Verdoorn Law (KV)). In this context, agriculture has a major role as a provider of cheap food and inputs, acting to

\footnotetext{
${ }^{1}$ Notice that the last input-output matrix available for Brazil is from 2005 and the last year with statistics about the value added of informal activities is from 2007. (For details, see Hallak (2012))
} 
mantain external competitiveness and to fight poverty (Rada 2006). Moreover, agriculture's exports play an important role in countries like Brazil.

In this article, we assess the sectoral contribution to economic growth of three major sectors: agriculture and live stock, industry, and services. The decomposition results for output growth in Brazil are examined in two periods: 2000-2005 and 2006-2011. Following the Structuralist literature, sustainable economic growth relies on sectoral structural change that culminates in a positive labour productiviy growth rate and a robust demand which in turn creates jobs in dynamic sectors.

Table 1 displays the sectoral value-added shares for the two periods. During 2000-2005, agriculture exhibited the lowest share of the output of the economy. Industry represented about per cent. The services showed the larger share of aggregate output. Each sector weight in the total value-added, highlights the sectoral contribution to the output generation.

Comparing the results of the first and second periods, Table 1 documents the rising of shares of services in total output. In contrast, the participation of

agriculture and industry diminished. Kaldor $(1975,1968)$ and Chang $(2011)$ stress that high tech services function as a complement to manufactuing, the former being unable to promote economic growth. According to structuralists, manufacturing is the engine of economic growth ${ }^{2}$. The growth of services pose a question about the sustainability of the economic growth in Brazil.

Tabela 1: Average sectoral participation of total Brazilian value-added, (\%).

\begin{tabular}{lcc}
\hline & \multicolumn{2}{c}{ Periods } \\
Sectors & $2000-2005$ & 2006-2011 \\
\hline Agriculture and live stock & 6.16 & 5.16 \\
Industry & 27.22 & 27.09 \\
Services & 66.62 & 67.75 \\
\hline Source: author's estimations.
\end{tabular}

Now let us turn the focus toward the decomposition of the output growth. The aggregate output results from the sum of sectoral outputs, $X=\sum_{i=1}^{n} X_{i}$. Differentiating the output equation with respect to time shows that the output growth rate stems from the weighted average sum of the sectoral output growth rates, $\hat{X}=\sum_{i=1}^{n} \chi_{i} \hat{X}_{i}$. Figure 1 documents the results. They reveal that service activities raised their contribution to aggregate output growth. Conversely, agriculture and industry's contribution dropped substancially. Between 2000 and 2005, the industry's growth rate represented aproximatelly 24.16 per cent of the whole output growth. In the second period, from 2006 to 2011, this share of growth diminished to 23.50 per cent; in other words, a drop of about 2.75 per cent. Compared to the first period (2000-2005), the decrease in agriculture was considerable; it fell from 9.81 per cent to 4.65 percent, a drop of 52 per cent. Conversely, services increased their share from 66.02 to 71.85 per cent, provoking a positive impact on the aggregate output growth. An indepth sectoral analysis allows us to verify that the structural change towards

\footnotetext{
${ }^{2}$ The Kaldor-Verdoorn (KV) Law is vital in explaining the process of economic growth and the standing of manufacturing as the engine of growth. This sector is unique in being able to present static and dynamic scale economies. Dynamic economies of scale come from learning by doing and induced innovations during the productive process.
} 
services (likelly intensive labour services with small labour productivity ) explained part of the economic growth in Brazil. Note that it was not high tech services that promoted economic expansion but labour intensive services, e.g., trade and commerce.

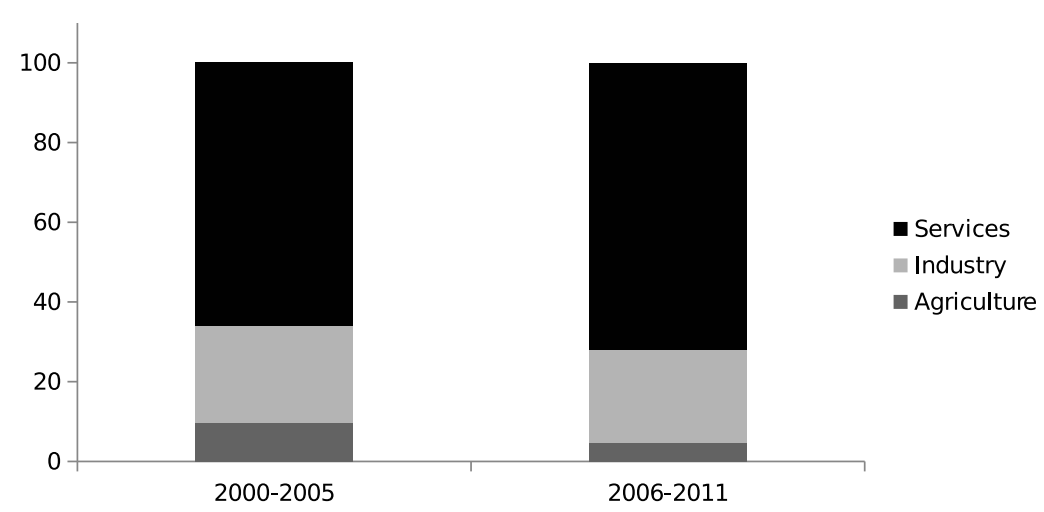

Source: author's estimations

Figura 1: Sectoral contribution to output growth in Brazil (\%)

A reverse structural change is not compatible with the internacional evidence in countries that achieved sustainable growth (Ocampo (2009); Roncolato (2013)). Such cases are related to the South Asian experiance after the 1950s, mainly that of South Korea. There, structural transformation occured in favour of manufacturing and high tech services (Rada and Taylor, 2006). In summary, the results for Brazil reveal a diminishing importance of industry in explaining economic growth.

The analysis of the decomposition of growth therefore, shows that the structural change toward services provoked the rise of output. Despite the smaller importance of the industry in explaining economic growth, this sector is still central to boost econonomic activity via dynamic scale economies. Moreover, after analysing the data it seems that the growing contribution of the service sector to growth remains concentrated in low labour productivity activities (Rada (2006); and Ocampo (2009)). If this trend persists, an unsustainable economic performance may emerge, according to the structuralist literature.

\section{The Structuralist Model and the Data}

This section presents the mathematical model and the data. First let us begin presenting the model in level and growth terms. The antecedents of the model are Rada $(2007,2012)$ and Morrone $(2015 a)$. Next we exhibit the data. We used the Social Accounting Matrix from Morrone (2015b) as our main data source. Morrone (2015b) attempted to overcome the lack of statistics about informal and formal sectors by employing techniques developed by Rada (2010) and data from Hallak (2012). 


\subsection{The Structuralist Model}

The model presented here is standard. It represents a surplus labour economy with two sectors, two commodities, and three economic classes - a capitalist, a formal worker, and an informal worker respectively. To build the model, we took into account the structural features of the Brazilian economy. We borrowed the model from Rada (2007).

The two main activities in the analysis are the informal sector $(n)$ and the formal sector $(t)$. The informal sector $(n)$ produces a nontradable $(N)$ good while the latter manufactures a tradable $(T)$ good. They are imperfect substitutes. Private income is distributed among capitalists in the formal sector, workers in the formal sector, and workers in the informal sector. Capitalists consume the formal good and save. Workers consume a constant share of their income in the consumption of both goods. The formal sector makes a commodity that can be consumed, invested, or exported. By this token, the foreign sector supplies intermediate goods to the modern sector. Table 2 exhibits the schematic Social Accounting Matrix (SAM), and its data source for a two-sector economy.

\section{Employment, Output, Investment and Net Exports determination for the Model in Level Terms}

Let's start the analysis by delving into the specifics concerning the functioning of labour markets. Here we assume full employment, that is, workers can always find a job in the informal sector. In other words, the informal sector works as a reservoir of labour, expanding during recessions and shrinking during economic recoveries. The equation formalizes the labour market behaviour.

$$
l_{n}=l-l_{t}
$$

Where $l_{t}$ and $l_{n}$ stands for the number of employed workers in the formal and informal sectors respectively.

The labour compensation in the informal sector is $w_{n}=\epsilon_{n} z_{n}$; hence, this implies an unclear distinction between capital and labour income. The transfer of workers from the informal sector (a low labour productivity sector) to the formal sector (a high labour productivity sector) boosts labour productivity in the whole economy (Rada 2007, Morrone 2015a). Having a higher capital-labour ratio, the formal sector can increase the productivity of each additional worker.

The informal sector is supply-constrained, meaning that prices will adjust to achieve equilibrium in the short/medium term. Labour productivity is equal to the informal sector value-added divided by the informal sector labour $\left(l_{n}\right)$. We can rewrite the equation as:

$$
y_{n}=\epsilon_{n} l_{n}
$$

Aggregate supply $\left(x_{n}\right)$ is presented below:

$$
c_{w n}^{n} l_{n}+c_{w t}^{n} l_{t}=x_{n}
$$

where $c_{w n}^{n}$ and $c_{w t}^{n}$ stand respectively for the consumption of the informal good by workers in the informal and formal sectors. 
Tabela 2: A social accounting matrix for a two-sector economy.

\begin{tabular}{|c|c|c|c|c|c|c|c|c|}
\hline \multirow{3}{*}{$\begin{array}{l}\text { SAM for Brazil } \\
\text { (1) Formal }\end{array}$} & \multicolumn{3}{|c|}{ Costs } & \multicolumn{2}{|r|}{ Use of income } & \multirow[b]{2}{*}{ Exports $(\mathrm{F})$} & \multirow[b]{2}{*}{$\begin{array}{l}\text { Accumulation } \\
(\mathrm{G})\end{array}$} & \multirow[b]{2}{*}{ Totals $(\mathrm{H})$} \\
\hline & Formal (A) & $\begin{array}{l}\text { Informal } \\
\text { (B) }\end{array}$ & $\begin{array}{l}\text { Formal households } \\
\text { (C) }\end{array}$ & Business (D) & $\begin{array}{l}\text { Informal hou- } \\
\text { seholds (E) }\end{array}$ & & & \\
\hline & \multicolumn{2}{|c|}{ Intermediate inputs } & $\begin{array}{l}\text { Formal HH con- } \\
\text { sumption of formal } \\
\text { goods (TRU) }\end{array}$ & & 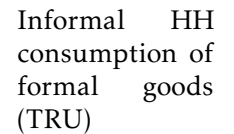 & $\begin{array}{l}\text { Foreign de- } \\
\text { mand (TRU) }\end{array}$ & $\begin{array}{lr}\text { Capital } & \text { Accu- } \\
\text { mulation } & \text { of } \\
\text { formal } & \text { goods } \\
\text { (TRU) } & \end{array}$ & $\begin{array}{l}\text { Formal sector } \\
\text { output }\end{array}$ \\
\hline (2) Informal & \multicolumn{2}{|c|}{ (I-O Matrix/TRU) } & $\begin{array}{l}\text { Formal HH con- } \\
\text { sumption of infor- } \\
\text { mal goods (TRU) }\end{array}$ & & $\begin{array}{l}\text { Informal } \mathrm{HH} \\
\text { consumption of } \\
\text { informal goods } \\
\text { (TRU) }\end{array}$ & & & $\begin{array}{l}\text { Informal sector } \\
\text { output }\end{array}$ \\
\hline $\begin{array}{l}\text { (3) Formal La- } \\
\text { bor }\end{array}$ & $\begin{array}{l}\text { Wages } \\
\text { (TRU) }\end{array}$ & & & $\begin{array}{l}\text { Dividends and inte- } \\
\text { rest paid to formal } \\
\text { labor (CEI) }\end{array}$ & & & & $\begin{array}{l}\text { Formal } \mathrm{HH} \text { in- } \\
\text { come }\end{array}$ \\
\hline $\begin{array}{l}\text { (4) Formal Busi- } \\
\text { ness }\end{array}$ & $\begin{array}{l}\text { Profits } \\
\text { (TRU) }\end{array}$ & & & & & & & $\begin{array}{l}\text { Business in- } \\
\text { come }\end{array}$ \\
\hline $\begin{array}{l}\text { (5) Informal La- } \\
\text { bor }\end{array}$ & & $\begin{array}{l}\text { Wages and } \\
\text { profits } \\
\text { (TRU) }\end{array}$ & & $\begin{array}{l}\text { Dividends and inte- } \\
\text { rest paid to infor- } \\
\text { mal labor (CEI) }\end{array}$ & & & & $\begin{array}{l}\text { Informal } \mathrm{HH} \text { in- } \\
\text { come }\end{array}$ \\
\hline (6) Government & $\begin{array}{l}\text { Taxes on } \\
\text { production } \\
\text { (TRU) }\end{array}$ & & $\begin{array}{l}\text { Direct and indirect } \\
\text { tax paid by formal } \\
\text { HH (TRU/CEI) }\end{array}$ & Corporate tax (CEI) & & $\begin{array}{l}\text { Indirect } \\
\text { (TRU) }\end{array}$ & $\begin{array}{l}\text { Indirect } \\
\text { (TRU) }\end{array}$ & Govern. income \\
\hline (7) Imports & $\begin{array}{l}\text { Imported } \\
\text { inputs } \\
\text { (TRU) }\end{array}$ & & $\begin{array}{l}\text { Imports (final go- } \\
\text { ods) (TRU) }\end{array}$ & $\begin{array}{l}\text { Buseiness net trans- } \\
\text { fers of income to } \\
\text { the rest of the world } \\
(\mathrm{CEI})\end{array}$ & & & & $\begin{array}{l}\text { Payments to the } \\
\text { rest of the world }\end{array}$ \\
\hline (8) Savings & & & $\begin{array}{l}\text { Formal HH saving } \\
\text { (CEI) }\end{array}$ & $\begin{array}{l}\text { Business saving } \\
\text { (CEI) }\end{array}$ & $\begin{array}{l}\text { Informal HH sa- } \\
\text { ving }(\mathrm{CEI})\end{array}$ & $\begin{array}{l}\text { Foreign saving } \\
\text { (CEI) }\end{array}$ & $\begin{array}{l}\text { Total capital ac- } \\
\text { cumulation }\end{array}$ & \\
\hline
\end{tabular}


In contrast, the formal sector operates with excess capacity. It functions as a quantity-clearing or demand-constrained sector. Hence output changes to accommodate disturbances in other variables. Capital stock is present in the modern sector only. In Keynesian fashion, the investment, $i_{t}$, responds to animal spirits (or autonomous investment, $z_{0}$ ), profits and accelerator. It is a function that includes the output of the formal sector $\left(x_{t}\right)$, profits $(\Pi)$, and the accelerator $\left(z_{2}\right)$ as explicative variables.

$$
i_{t}=z_{0}+z_{1} \Pi+z_{2} x_{t}
$$

Following analogous procedures for the formal sector, we can write the sectoral balance equation for this sector as:

$$
c_{\pi}+c_{w t}^{t} l_{t}+c_{w n}^{n} l_{n}+k_{t}+i_{t}=x_{t}
$$

where $c_{\pi}$ is the capitalist consumption of formal goods and $k_{t}$ is tradable good exports.

We assume that both workers consume the nontradable good. We employ the Linear Expenditure System (LES) to add the consumer choice into the analysis. Note that workers consume a minimum amount, $\theta$, defined as the floor-level consumption of the informal good. A positive $\theta^{3}$ indicates an income-inelastic informal good demand and an income-elastic formal sector's good demand. The remaining income is separated between the two goods, in this case, $(1-\alpha)$ and $(1-\beta)$. For more details, see Morrone (2015a).

Furthermore, exports $\left(k_{t}\right)$ and imports $\left(m_{t}\right)$ are endogenous, responding to price and output changes only. The two equations are shown as:

$$
\begin{aligned}
& k_{t}=\chi^{0}(\rho)^{\chi} x_{f} \\
& m_{t}=\phi^{0}(\rho)^{-\phi} x_{t}
\end{aligned}
$$

where $\rho, \rho=\frac{e P^{*}}{P_{t}}$, is the real exchange rate, $x_{f}$ is the foreign demand for the modern sector goods, $p_{t}$ is the price of the modern sector, $p^{*}$ is the foreign price, and $e$ is the nominal exchange rate. The parameters $\phi$ and $\chi$ stand for exports and imports' trade elasticities.

Lastly, the investment-saving balance $s=i_{t}$ (closure of the model) follows the Keynesian tradition; that is, demand triggers output. In other words, the output level rises in response to a change in aggregate demand for the formal sector. (For more details about the model and for information on price determination, see Morrone (2015a)).

\section{How the Model in Growth Terms Works for the Formal Sector}

This section presents the model in growth terms. A set of equations can display the model's behavior in the short term. As mentioned earlier, the model works with full underemployment, since all workers can find jobs in the informal sector. The growth rate of employment is endogenous, being the difference between the output growth rate and the labour productivity growth rate. The latter stems from the Kaldor-Verdoorn Law (KV).

\footnotetext{
${ }^{3}$ See Taylor (1976, p. 219-222) for more details.
} 
Starting with $x \equiv l \epsilon$, where $x$ is output, $l$ stands for labour, and $\epsilon$ is the average labour productivity, we can calculate labour growth rate as: $\hat{l}=\hat{x}-\hat{\epsilon}$. Here, following the Kaldor-Verdoorn relationship (Kaldor, 1968), the growth rate of the aggregate labour productivity $(\hat{\epsilon})$ depends on the autonomous productivity $(\epsilon)$ and on output growth $(\hat{x})$ as follows:

$$
\hat{\epsilon}=\epsilon+\gamma_{0} \hat{x}
$$

The term on the right, $\gamma_{0}$, reacts to industrial policy, human capital, and trade openness (Rada 2012). Replacing relation 8 (the KV Law) in the labour growth equation we have as a result:

$$
\hat{l}=\left(1-\gamma_{0}\right) \hat{x}-\epsilon
$$

The equation 9 means that employment grows if demand grows faster than autonomous labour productivity and KV coefficient, $\gamma_{0}$.

Turning now to output growth, we can examine which variables drive it. As before, demand triggers output growth in the short term. The model's closure follows Keynesian lines. Equation 10 exhibits the macroeconomic balance between saving and investment. The total saving is the sum of saving out of profits and foreign saving,

$$
s \pi x+e\left(\frac{p^{*}}{p_{t}}\right) f x-k-i=0
$$

where $\pi$, and $\mathrm{f}\left(f=\frac{m}{x_{t}}\right)$ stand respectively for the profit-share and the share of imports in supply.

Starting with the saving-investment balance equation (10) and abstracting from intermediate goods this equation can be solved to $x$ as follows.

$$
x=\frac{k+i}{s \pi+e\left(\frac{p^{*}}{p_{t}}\right) f}
$$

Total differentiation of the equation in respect to exports $\left(k_{t}\right)$, investment $\left(i_{t}\right)$, saving rate $(s)$ and real exchange rate, $e_{r}=e\left(\frac{p^{*}}{p_{t}}\right)$, produces the equation for output growth:

$$
\hat{x}=\frac{i}{i+k} \hat{i}+\frac{k}{i+k} \hat{k}+\frac{s \pi}{s \pi+e_{r} f} \sigma(\hat{w}-\hat{\epsilon})-\frac{e_{r} f}{s \pi+e_{r} f} \hat{e}_{r}
$$

or,

$$
\hat{x}=\mu_{1} \hat{i}+\left(1-\mu_{1}\right) \hat{k}+\mu_{2} \sigma(\hat{w}-\hat{\epsilon})-\left(1-\mu_{2}\right) \hat{e}_{r}
$$

where:

$\frac{i}{i+k}=\mu 1$, and $\mu_{2}=\frac{s \pi}{s \pi+e_{r} f}$;

$\hat{w}=$ growth rate of the wages in the formal sector;

$\hat{\epsilon}=$ growth rate of the labour productivity in the formal sector.

The saving's growth rate, $\hat{s}$, responds negatively to a higher wage share, $\hat{s}=-\sigma \hat{\psi}$, where $\hat{\psi}=\hat{w}-\hat{\epsilon}$ stands for the wage share's growth rate in the formal sector and $\sigma$ is the elasticity of saving with respect to the wage share. Investment and exports react to demand and wages (or profits) as follows:

$$
\hat{i}=\hat{i}_{0}+\phi_{x} \hat{x}-\phi_{\psi} \hat{\psi}
$$




$$
\hat{k}=\hat{k}_{0}+\theta_{x} \hat{x}-\phi_{\psi} \hat{\psi}+\theta_{e} \hat{e}_{r}
$$

where $\hat{i}_{0}$ is the autonomous investment and $\hat{k}_{0}$ is the autonomous growth rate of exports, also called the incoming (or trend) growth rate of investment and the incoming growth rate of exports respectively. Additionally, employing the equations 14 and 15, and adding further algebraic manipulation, we can rewrite the equation for output growth as:

$$
\hat{x}=\chi_{1} \hat{i}_{0}+\chi_{2}(\hat{w}-\hat{\epsilon})+\chi_{3} \hat{e}_{r}+\chi_{4} \hat{k}_{0}
$$

where:

$$
\begin{gathered}
\chi_{1}=\frac{\mu_{1}}{1-\mu_{1} \phi_{X}+\left(1-\mu_{1}\right) \theta_{X}} \\
\chi_{2}=\frac{\left(1-\mu_{1}\right) \theta_{\psi}+\mu_{1} \phi_{\psi}-\mu_{2} \sigma}{1-\mu_{1} \phi_{x}+(1-\mu 1) \theta_{x}} \\
\chi_{3}=\frac{\left(1-\mu_{1}\right) \theta_{e}-\left(1-\mu_{2}\right)}{1-\mu_{1} \phi_{x}+\left(1-\mu_{1}\right) \theta_{x}} \\
\chi_{4}=\frac{1-\mu_{1}}{1-\mu_{1} \phi_{x}+\left(1-\mu_{1}\right) \theta_{x}}
\end{gathered}
$$

A precondition for model economic meaning is that $\chi_{1}$ and $\chi_{4}$ must be positive. This requirement is met when the accelerator $\left(\phi_{x}\right)$ is closer to one (For details, see Rada (2007)). The remaining two coefficients $\chi_{2}$ and $\chi_{3}$ measure the impact of changes in income distribution and capture the effect of exchange rate depreciation on exports. A $\chi 2$ lower than one makes the economy wage-led, a situation where higher wages provoke a surge in domestic demand that compensates the very small negative impact on exports and on investment. Conversely, $\chi_{2}>1$ indicates a growth regime led by profits. In this case, higher profits stem investment triggering economic activity. Employing equations (8), (9), and (16) we can rearrange them to show the key macroeconomic variables:

$$
\begin{gathered}
\hat{x}=\frac{1}{1-\gamma_{0} \chi_{2}}\left[\chi_{2}(\epsilon-\hat{w})+\chi_{1} \hat{i}_{0}+\chi_{3} \hat{e}_{r}+\chi_{4} \hat{k}_{0}\right] \\
\hat{x}=\frac{1}{1-\gamma_{0} \chi_{2}}\left[\epsilon+\gamma_{0}\left(\chi_{1} \hat{i}_{0}+\chi_{3} \hat{e}_{r}-\chi_{2} \hat{w}+\chi_{4} \hat{k}_{0}\right]\right. \\
\hat{\imath}=\frac{1}{1-\gamma_{0} \chi_{2}}\left[\left(1-\gamma_{0}\right)\left(\chi_{1} \hat{i}_{0}+\chi 3 \hat{e_{r}}-\chi_{2} \hat{w}+\chi_{4} \hat{k}_{0}\right)-\left(1-\chi_{2}\right) \epsilon\right]
\end{gathered}
$$

Having set these equations, we are able to analyse how the key variables (output, labour productivity, and formal employment) react to exogenous shocks. A higher autonomous productivity $\epsilon$, ceteris paribus, raises average labour productivity setting a chain impact on output and employment. The results can stimulate output and employment growth or not. Once $\chi_{2}$ is negative (the wage-led regime case), output and employment drop. On the contrary, output and employment grow if $\chi_{2}>1$ (the profit-led case). Finally, an intermediary case occurs when the economy is weakly profit-led $\left(0<\chi_{2}<1\right)$. 
In this case only employment growth deteriorates. Visually, these regimes can be presented in Figure 2 (a), and (b), borrowed from Rada (2012).

Rada $(2007,2012)$ sets up an interesting model that explores the determination of output, employment and labour productivity in the formal sector in two scenarios: a strongly profit-led economy and a weakly profit-led regime. In Figure 2, the intersection between the Kaldor-Verdoorn relation and output curves indicates labour growth. In this figure, effective demand is weakly profit-led. For instance labour growth is zero on the employment growth contours (lines containing a 45 degree slope). When equilibrium moves to the northwest region, employment creation diminishes, leading to a phenomenon usually known as jobless growth. From the analysis of the figure, an increase in the labour productivity growth rate does not substantially increase output growth.

In contrast, we have the case for a strong profit-led regime in Figure 2 (b). Here the output growth schedule's slope is shallow. In this scenario, a rise in the labour productivity growth rate (an upward shift of the KV schedule) stimulates employment growth considerably. Last but not least, a wage-led regime will present a negative sloped output growth schedule. (For more details, see Rada (2007) or Ocampo (2009)).

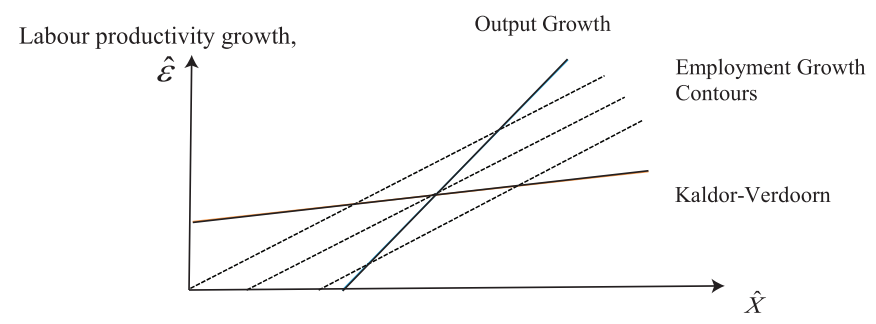

(a): Output, productivity, and employment equilibrium determination when output schedule has a slope higher than 45 degree.

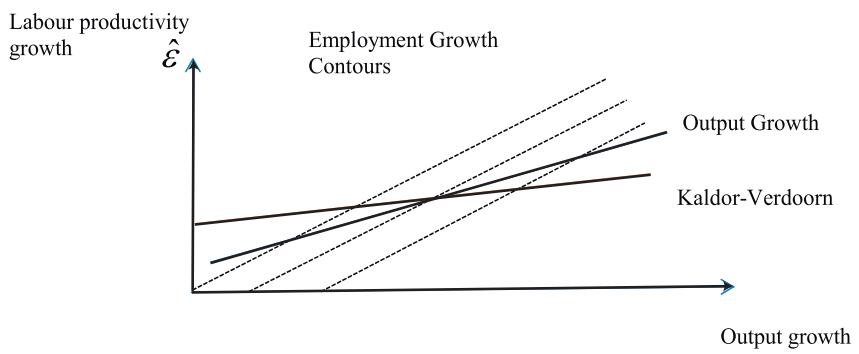

(b): Output, productivity, and employment equilibrium when output schedule presents a slope lower than 45 degree).

Source: author's estimations

Figura 2: Output, labour produtivity and employment for the formal sector 


\subsection{The Social Accounting Matrix and Calibration}

Our Social Accounting Matrix (SAM) comes from Morrone (2015b). To construct the SAM, Morrone (2015b) used data from the System of National Accounts (SNA-IBGE, 2011). Following Rada (2010), he applied the shares of output from informal and formal sectors as weights to estimate the size of the two sectors. Those statistics about informal value added come from Hallak (2012). Thereafter, he aggregated all the informal sector transactions into a unique informal sector. A similar procedure was adopted to aggregate the set of formal activities into the formal sector. (For more details, see Morrone (2015a)). In this study, the informal sector was defined as a subdivision of the household sector in the System of National Accounts - SNA, characterized by a particular way of organizing the production and an unclear division between labour and capital. This sector includes businesses not officially registered. Informal labour has two main component parts: autonomous labour and employees without legal contracts. For simplicity, he assumed that the informal sector uses informal labour only.

The SAM includes two sectors and two households. The formal sector incorporates high productivity agriculture, industry and services. The Brazilian SAM for 2006 attempts to measure informality and its relation to the formal sector. The analyses of the SAM and its components reveal the importance of the informal sector and the relative degree of structural interdependence within the Brazilian economy. Table 3 illustrates important statistics for the two sectors.

At a glance, Table 3 shows a substantial difference in labour productivity between the two sectors. Formal sector workers are on average 8.4 times more productive than workers in the informal sector. Rada (2010) estimated that formal workers are 9.1 times more productive than informal workers in India for 1999. In this vein, the creation of jobs in the formal sector and further increases in productivity are important requirements for sustainable economic growth.

However, to achieve sustainable growth, improvements in the labour productivity of informal sector workers are required (Lewis 1954). The increase in productivity in the informal sector releases labour that can migrate towards the formal sector. The transfer of workers from the informal sector to the formal sector leads to a rise in average labour productivity in the whole economy (de Vries et al., 2012). This is a precondition for many developing economies that pursue a robust and sustainable growth.

Tabela 3: Summary indicators for Brazil for year 2006.

\begin{tabular}{lc}
\hline \multicolumn{2}{c}{ Economic Indicators } \\
\hline Relative labour productivity (formal/informal) & 8.39 \\
Relative wage (formal/informal) & 4.38 \\
Informal employment (\% of total) & 57.59 \\
Capitalist's savings rate & 38.12 \\
Saving rate formal HH (\%) & 9.45 \\
Saving rate informal HH (\%) & 3.82 \\
Current account balance/GDP (\%) & -0.97 \\
\hline Source: Morrone (2015b)
\end{tabular}


Table 3 reveals a strong inequality between the two sectors. Labour remuneration in the formal sector is on average about four times higher than in the informal sector. Rada (2010) found that the relative wage (formal/ informal) was 5.5 for India during the late 1990s. When we consider that labour remuneration in the informal sector includes both capital and labour remunerations, this difference should be even greater.

In addition, there are also significant differences in terms of employment indicators. The informal sector employs 53.70 million people, while the formal sector absorbs only 39.54 million. This illustrates the informal sector's role as a creator of jobs and its capability to absorb surplus labour.

As we turn now to the main parameters and exogenous variables of the model, it is vital to underscore their importance. They serve as key variables to feed our model. Table A.1 in the appendix, displays the incoming (trend) growth rates of macroeconomic variables and parameters of the model. Most of the parameters come from national accounting, literature, or chosen ad hoc. In this sense, a major data source is the SAM for 2006 from Morrone (2015b).

The share of investment $\mu_{1}=\frac{i}{i+k}$ is 0.54 in Brazil, and the share of savings to total savings is 24 per cent in the country for 2006. The profit-share comes from the national accounting data, being equal to 39 per cent. The domestic savings- total savings share $\left(\mu_{2}\right)$ is $38 \%$. Savings from capitalists, formal and informal workers are $38,9.4$, and 3.8 per cent respectively.

We chose ad hoc plausible values for the remaining exogenous variables and parameters. The accelerator, $\phi_{x}$, is equal to one in agreement with the international empirical evidence (See Naastepad, 2006). A higher wage share has a negative effect on investment and exports (both elasticities are equal to -0.20). The external demand reacts to an exchange rate depreciation with an elasticity of one. Lastly, according to Thirlwall (1983), the Kaldor-Verdoorn coefficient $\left(\gamma_{0}\right)$ is 0.3 .

These parameter values help to solve the remaining variables. Other parameters and exogenous variables such as $\chi_{1}, \chi_{2}, \chi_{3}$, and $\chi_{4}$ come from macroeconomic data. In this way, $\chi_{2}=0.02$ indicates that the economy is weakly profit-led. As before, a positive and lower than one indicates a weakly profitled economy. In other words, changes in the wage-share have an impact on output through $\chi_{2}$. The remaining parameters and growth rates of exogenous variables are in the appendix (Table 5).

\section{Comparative Statics' Results for the Formal Sector}

This section discusses the simulation results of four experiments: a surge of autonomous investment growth rate from 1.5 to $2 \%$, a rise of wages growth rate trend from 1.5 to $3 \%$, a exchange rate depreciation changing from -0.8 to $1 \%$, and an increase in the productivity growth rate (autonomous productivity) from 0.15 to $1 \%$. Table 4 shows the results.

The first row in the table 4 describes the base run results of the model that reproduces the average annual growth rates of formal output, productivity, and employment in Brazil from 2000-2008. The remaining rows display simulation results. Let us begin with the first scenario in row two when a rise in autonomous investment emerges. The results show that the statistics improve all over the border. The key macroeconomic variables (output, productivity, and employment) rise substantially after the investment shock. The 
growth of the three macro variables implies that structural change obviously takes place in favour of formal activities.

What does the model predict for the economy when formal wages growth rate increases? In this scenario, both output, labour productivity and employment growth rates present a moderate decrease. It occurs because the economy is weakly profit-led. This outcome might seem inaccurate since the Brazilian economy growth recently was attached to income redistribution. We argue that income transfers answer at least part of the growth in Brazil. In this vein, a positive international scenario, income transfers, and changes in the personal distribution of income triggered growth, overcoming the mild negative impacts of wage growth on output. Carvalho (2016) show that shifts in personal distribution of income can boost demand even if the economy is profit-led. Using econometrics, Araújo (2012) found that Brazil was strongly profit-led from 2001 to 2009.

Furthermore, our result is consistent with the Classical-marxian approach where the profit rate triggers growth in investment and accumulation rates. For instance, Marquetti (2009) employing a Classical-marxian model based on the Cambridge equation, found that Finland and Ireland were driven by profits between 1960 and 2004. Other studies, such as Von Arnim and Rada (2011), obtained similar results using alternative methods for the study of other countries.

So what is the effect of an exchange rate depreciation? The model's outcome suggests that output, productivity, and employment growth rate diminish considerably. The positive impact on exports is insufficient to offset the higher costs of imported inputs. By the same token, price inelastic capital goods imports can create a contractionary outcome as a response to an exchange rate depreciation (Krugman 1978). Storm (1997) and Razmi (2007) present a recent discussion about possible contractionary effects of exchange rate depreciation. Because $\chi_{3}$ is negative, exchange rate depreciation hurts economic performance. Since Brazil is dependent on capital goods imports, this result is not surprising. Similar results were found in India by Rada (2012) and in Cuesta (1990).

Although Serrano (2012) state that Brazil follows a wage-led regime, our estimates indicate that it was not the increase in wages that promoted economic expansion. Our results suggest that the appreciation of the exchange rate was the key in fostering economic activity in the short/medium term, not wages. A more appreciated rate allows the country to import more capital goods, potentially reducing costs and improving labour productivity. Moreover, Morrone (2016) found empirical evidence that an appreciated exchange rate stimulated the growth of the Brazilian manufacturing productivity in the period 2004-2013. Frenkel (2006) argue that an exchange rate appreciation might increase the level of economic activity in the short/medium term, although not in the long term.

The last row of the table shows that a surge in autonomous labour productivity $(\epsilon)$ leads to economic expansion (as a result of a successful industrial policy or a higher human capital growth rate). In the weakly profit-led economy of Brazil, a higher autonomous productivity stimulates output and productivity through the KV Law. Figure 2 (a) illustrates this result. A rise in productivity causes an upward shift on the KV schedule, leading to higher output and productivity growth rates. In contrast, the new equilibrium rests on a higher employment growth contour, diminishing employment growth 
substantially.

Tabela 4: Comparative static's results for the formal sector in Brazil, $(\%)$

\begin{tabular}{lcccc}
\hline & \multicolumn{3}{c}{$\begin{array}{c}\text { Growth (\%) } \\
\text { Productivity* }\end{array}$} & Employment \\
\hline Base run & & 3.34 & 1.15 & 2.19 \\
Investment growth & $1.5-2 \%$ & 3.83 & 1.30 & 2.53 \\
Wage growth & $1.5-3 \%$ & 3.31 & 1.14 & 2.17 \\
Exchange depreciation & $1 \%{ }^{* *}$ & 2.83 & 1.00 & 1.83 \\
Productivity growth & $0.15-1 \%$ & 3.36 & 2.01 & 1.35 \\
\hline Source: author's calculations. \\
* Productivity stands for average labour productivity for the formal sector only. \\
${ }^{* *}$ A rise in exchange rate depreciation from -0.8 to 1\%
\end{tabular}

\section{Conclusion}

This paper has introduced a model to evaluate the effects of macroeconomic policies on the economy. Specifically, we investigate the short/medium term results of four exercises: a rise in autonomous investment, a surge in formal wages growth rate, an exchange depreciation, and an increase in the growth of autonomous labour productivity.

The results show that the Brazilian economy is weakly profit-led. In this context, a redistributive policy towards labour and exchange rate depreciation does not foster economic growth. On the other hand, policies that provoke a surge in autonomous investment (e.g., via industrial policy), and in labour productivity (e.g. higher human capital) positively affect the economy, boosting output and employment. Our findings underscore the importance of these macroeconomic policies to engender economic expansion.

\section{Referências Bibliográficas}

Araújo, L.; Gala, P. (2012), 'Regimes de crescimento econômico no brasil: Evidências empíricas e implicações de política', Estudos Avançados USP 26(75), 41-56.

Carvalho, L.; Rezai, A. (2016), 'Personal income inequality and aggregate demand', Cambridge Journal of Economics 40(2), 491-505.

Chang, H. J. (2011), 'Manufacturing: statements, opening statements and manufacturing: statements, rebuttal statements', The Economist. Acesso em 20 de mar 2014.

Cuesta, J. L. L. (1990), Is-fm macroeconomics: General equilibrium linkages of the food market in colombia, in L. Taylor, ed., 'Social Relevant Policy Analysis: Structuralist Computable General Equilibrium Models for the Developing World', Vol. 1, The MIT Press.

Frenkel, R.; Taylor, L. (2006), 'Real exchange rate, monetary policy and employment', Working Papers n. 19, United Nations, Department of Economics and Social Affairs. 
Hallak, J.; Namir, K. K. L. (2012), 'Setor e emprego informal no brasil: Análise dos resultados da nova série do sistema de contas nacionais - 2000/07', Economia e Sociedade 21(1), 93-113.

Kaldor, N. (1968), 'Productivity and growth in manufacturing industry: a reply', Economica 35(140), 385-391.

Kaldor, N. (1975), 'Economic growth and the verdoorn law. a comment on mr. rowthorn's article', Economic Journal 85, 891-896.

Krugman, P.;Taylor, L. (1978), 'Contractionary effects of devaluation', Journal of International Economics 8(3), 445-456.

Lewis, W. A. (1954), 'Economic development with unlimited supplies of labour', Manchester School 28, 139-191.

Marquetti, A. A.; Koshiyama, D. A. D. (2009), 'O aumento da lucratividade expande a acumulação de capital? uma análise de causalidade de granger para países da ocde', Revista de Economia Contemporãnea (REC) 13(3), 367390.

Morrone, H. (2015a), 'Assessing the impact of distributive policies on the brazilian economy using an scge model', Economic Systems Research 27, 118.

Morrone, H. (2015b), 'Formal and informal sectors in a social accounting matrix for brazil', Revista Análise Econômica UFRGS 64(33), 27-49.

Morrone, H. (2016), 'O aumento da demanda estimula a produtividade? uma análise de causalidade de granger para a manufatura brasileira', Ensaios FEE 36(4), 979-1004.

Ocampo, A. C.; Rada, C. T. L. (2009), Growth and policy in developing countries: A structuralist approach, Columbia University Press, New York.

Rada, C. (2007), 'Stagnation or transformation of a dual economy through endogenous productivity growth', Cambridge Journal of Economics 31, 711740 .

Rada, C. (2010), 'Formal and informal sectors in china and india', Economic Systems Research 22(2), 129-153.

Rada, C. (2012), 'Structural transformation in china and india: A note on macroeconomic policies', Structural Change and Economic Dynamics 23(3), 264275.

Rada, C.; Taylor, L. (2006), 'Developing and transition economies in the late 20th century: Diverging growth rates, economic structures, and sources of demand', Working Papers 34, United Nations, Department of Economics and Social Affairs.

Razmi, A. M. (2007), 'The contractionary short-run effects of nominal devaluation in developing countries: Some neglected nuances', International Review of Applied Economics 21(5), 83-109. 
Roncolato, L.; Kucera, D. (2013), 'Structural drivers of productivity and employment growth: a decomposition analysis for 81 countries', Cambridge Journal of Economics 38(2), 399-424.

Serrano, F.; Summa, R. (2012), 'Macroeconomic policy, growth and income distribution in the brazilian economy in the 2000s', Revista Investigacion Econômica 71(282), 55-92.

Storm, S. (1997), 'Domestic constraints on export-led growth', Journal of Development Economics 52(1), 83-120.

Taylor, L.;Bacha, E. L. (1976), 'The unequalizing spiral: A first growth model for belindia', The Quarterly Journal of Economics 90(2), 197-218.

Thirlwall, A. (1983), 'A plain man's guide to kaldor's growth laws?', Journal of Post Keynesian Economics 5(3), 345-358.

\section{Apêndice A Source of data and parameters}

Table 1: Data for output from the System of National Accounts of the Brazilian Institute of Geografy and Statistics (1994-2011). Table of Resources and Uses." Federal Government.

http://www.ibge.gov.br/home/estatistica/economia/contasnacionais

Table 3: Data source on formal and informal activities was estimated by Morrone (2015b).

Table 4: Data source came from Morrone (2015b) and author's estimations.

Table 5: Data came from the Social Accounting Matrix for formal and informal activities estimated by Morrone (2015b). Moreover, data from the Institute of Geografy and Statistics (1994-2011), and "Instituto de Pesquisa Econômica Aplicada"(2009) 'Macroeconomic and Social Statistics' (ht tp: / / www . ipeadata . gov.br/) was also employed.

Tabela A.1: Economic parameters and exogenous growth rates.

\begin{tabular}{lc}
\hline \multicolumn{2}{l}{ Economic parameters and exogenous growth rates } \\
\hline (a) Major parameters \\
$\pi$ & 0.39 \\
$\mu_{1}$ & 0.54 \\
$\mu_{2}$ & 0.38 \\
$\gamma_{0}$ & 0.30 \\
$\chi_{1}$ & 0.97 \\
$\chi_{2}$ & 0.02 \\
$\chi_{3}$ & -0.28 \\
$\chi_{4}$ & 0.83 \\
$(\mathrm{~b})$ Growth rate of exogenous variables $(\%)$ \\
$\hat{w}$ & 1.58 \\
$\hat{e}_{r}$ & -0.8 \\
$\hat{i}_{0}$ & 0.15 \\
$\bar{\epsilon}$ & 1.50 \\
$\hat{k}_{0}$ & 2.00 \\
\hline \multicolumn{2}{c}{ Source: Morrone (2015b) and author's } \\
estimations.
\end{tabular}

